\title{
PENDIDIKAN GIZI MENGGUNAKAN MEDIA BUKU SAKU MENINGKATKAN PENGETAHUAN DAN PRAKTIK KONSUMSI SAYUR DAN BUAH PADA SISWA SEKOLAH DASAR
}

\author{
Nutrition Education with Pocket Book Increase Knowledge and Practice of Vegetable and Fruit \\ Consumption among Elementary Student \\ Fitria Laras Azadirachta ${ }^{1}$, Sri Sumarmi² \\ ${ }^{1}$ Program studi S1 Ilmu Gizi, Fakultas Kesehatan Masyarakat Universitas Airlangga, Surabaya \\ ${ }^{2}$ Departemen Gizi Kesehatan, Fakultas Kesehatan Masyarakat, Universitas Airlangga, Surabaya \\ Email: fitrialarasaza@gmail.com
}

\begin{abstract}
ABSTRAK
Rata-rata konsumsi sayur dan buah di Indonesia masih rendah. Kondisi ini dapat menyebabkan munculnya masalah gizi pada anak. Penelitian ini bertujuan untuk menganalisis pengaruh media buku saku terhadap peningkatan pengetahuan serta praktek konsumsi sayur dan buah pada anak sekolah dasar. Penelitian ini adalah quasy-experiment dengan pendekatan pre-test-post-test control group design. Besar sampel 60 siswa, 20 siswa SDN Kandang Tepus I sebagai kelompok kontrol yang diberi media leaflet dan 40 siswa SDN Kandang Tepus II sebagai kelompok intervensi diberi media buku saku. Pengetahuan dan praktik responden diukur menggunakan kuesioner. Praktik responden kelompok perlakuan dilihat menggunakan diari makan pada buku saku. Hasil independent $t$-test pada pre-test kedua kelompok menunjukkan tidak ada perbedaan pengetahuan $(\mathrm{p}=0,220)$ dan praktik $(\mathrm{p}=0,091)$ antara kedua kelompok. Hasil post-test juga menunjukkan tidak ada perbedaan pengetahuan $(\mathrm{p}=0,421)$ dan praktik $(\mathrm{p}=0,810)$ antara kedua kelompok. Hasil uji paired sample t-test kelompok perlakuan menunjukkan rata-rata pengetahuan pre-test dan post-test masing-masing $31,50$ dan 66,25 dan praktik 2,58 dan 3,08. Terdapat perbedaan signifikan pada pengetahuan ( $\mathrm{p}=0,000)$ dan praktik $(\mathrm{p}=0,000)$ antara sebelum dan sesudah diberi media buku saku. Pada kelompok kontrol, hasil uji Wilcoxon sign rank Test menunjukkan bahwa leaflet tidak mempengaruhi pengetahuan $(\mathrm{p}=0,052)$ namun mempengaruhi praktik $(\mathrm{p}=0,001)$. Berdasarkan hasil penelitian tersebut dapat diambil kesimpulan bahwa penggunaan media buku saku mempengaruhi pengetahuan dan praktik siswa.
\end{abstract}

Kata kunci: buku saku, pengetahuan, praktik

\section{ABSTRACT}

The average consumption of vegetables and fruits in Indonesia, is still low. This condition can cause the emergence of nutritional problems in children. The purpose of this study was to determine the effect of nutritional education using pocket book to increasing knowledge and practice of vegetables and fruits consumption among elementary students. This research was quasy experiment using pre-test post-test control group design. The sample size was 60 students consisting of 20 students of SDN Kandang Tepus I as control group treated with media leaflet and 40 students of SDN Kandang Tepus II as treatment group given the pocket book. The result of independent t-test in pre-test of booth groups shows that there was no difference in knowledge $(p=0.220)$ and practice $(p=0.091)$ between the two groups. Independent $t$-test result on post-test also shows was no difference in knowledge $(p=0.421)$ and practice $(p=0.810)$ between the two groups. The result of paired sample t-test of the treatment group showed the average of pre-test and post-test of knowledge score were 31.50 and 66.25 and the practice were 2.58 and 3.08. There were significant difference of knowledge $(p=0.000)$ and practice $(p=0.000)$ before and after being given pocket book. Wilcoxon sign rank test in the control group showed that leaflet did not affect knowledge $(p=0.052)$ but affect the practice $(p=0.001)$. It can be concluded that use of pocket book media influence the knowledge and the respondent practice.

Keywords: pocket book, knowledge, practice 


\section{PENDAHULUAN}

Gizi seimbang merupakan susunan pangan sehari yang mengandung berbagai zat gizi dengan jenis dan jumlah yang sesuai dengan kebutuhan tubuh (Balitbangkes RI, 2014). Salah satu pesan gizi seimbang yaitu memperbanyak konsumsi sayur dan buah sebanyak 300-400 gram per orang per hari (Kemenkes RI, 2014). Sebagian besar masyarakat Indonesia masih kurang mengonsumsi sayur dan buah (Balitbangkes RI, 2013). Faktor yang berhubungan dengan tingkat konsumsi sayur pada anak sekolah yaitu pendidikan ibu dan media informasi (Dhian, 2009), pendapatan orang tua, pengetahuan gizi, dan kebiasaan makan orang tua (Lestari, 2013).

Konsumsi sayur dan buah yang rendah dapat menyebabkan beberapa masalah gizi pada anak, salah satunya adalah obesitas pada anak usia sekolah (Anggraeni, 2016). Hasil penelitian yang dilakukan oleh Siagian, dkk. (2017), menyatakan bahwa ada hubungan antara konsumsi sayur dan buah terhadap kejadian obesitas pada anak sekolah dasar. Anak yang kurang konsumsi serat dapat mengalami gangguan saluran pencernaan, seperti mengalami konstipasi dan kegemukan (Manore, dkk., 2009).

Pengetahuan merupakan salah satu faktor yang mempengaruhi konsumsi sayur dan buah pada anak. Penelitian Dhaneswara (2016) dan Mohammad dan Madanijah (2015), menyatakan bahwa pengetahuan berhubungan dengan sikap seseorang dalam mengonsumsi sayur dan buah. Begitu pula dengan penelitian yang dilakukan oleh Mulyani, dkk. (2014) yang menyatakan bahwa adanya hubungan antara pengetahuan dengan perilaku gizi seimbang. Menurut Amalia, dkk. (2012), pengetahuan gizi anak kelas 4 dan 5 sekolah dasar tergolong rendah, sehingga diperlukan adanya pemberian pendidikan gizi untuk meningkatkan pengetahuan anak sekolah tentang sayur dan buah untuk meningkatkan konsumsi sayur dan buah pada anak usia sekolah.

Berdasarkan beberapa penelitian terdahulu menunjukkan bahwa pendidikan gizi dengan media buku saku efektif untuk meningkatkan pengetahuan siswa seperti penelitian yang dilakukan oleh Achmadi (2015) serta Eliana dan Sholikhah (2012). Buku saku merupakan media yang mampu menyampaikan pesan kesehatan dalam bentuk buku berukuran kecil $(10 \times 14 \mathrm{~cm})$ yang dapat berisi tulisan maupun gambar, serta terdapat tambahan lembar kosong diari makan yang digunakan untuk mencatat buah dan sayur apa saja yang dikonsumsi siswa selama penelitian. Tujuan dari penelitian ini adalah untuk menganalisis adanya pengaruh pendidikan gizi dengan media buku saku terhadap peningkatan pengetahuan dan praktik konsumsi sayur dan buah pada anak sekolah dasar.

\section{METODE}

Penelitian ini adalah quasy experimental dengan rancangan pre-test post-test control group design. Besar sampel ditentukan menggunakan total sampling, diperoleh 60 siswa, dengan rincian 20 siswa kelas 4 dan 5 SDN Kandang Tepus I sebagai kelompok kontrol yang diberi perlakuan dengan menggunakan media leaflet dan 40 siswa kelas 4 dan 5 SDN Kandang Tepus II sebagai kelompok perlakuan yang diberi perlakuan dengan media buku saku. Perlakuan yang diberikan berupa penyuluhan tentang pentingnya konsumsi sayur dan buah dengan media leaflet untuk kelompok kontrol dan buku saku untuk kelompok perlakuan. Bagian akhir buku saku terdapat lembar diari makan, yang digunakan siswa untuk menulis sayur dan buah apa saja yang dikonsumsi selama dilakukan penelitian.

Penelitian berlangsung selama 2 minggu, dengan rincian satu kali pertemuan setiap minggu. Pada pertemuan pertama, minggu pertama, kelompok kontrol dan perlakuan diberi penjelasan terlebih dahulu tentang pelaksanaan penelitian kemudian mereka diberi surat kesediaan untuk mengikuti penelitian ini dengan persetujuan orang tua. Hari berikutnya, siswa diminta untuk mengumpulkan surat kesediaan tersebut. Siswa yang bersedia mengikuti penelitian kemudian diminta untuk mengisi kuesioner data pribadi serta pre-test, kemudian dilanjutkan dengan penyuluhan tentang pentingnya mengonsumsi sayur dan buah menggunakan media leaflet (kontrol) dan buku saku (perlakuan). Siswa pada kelompok perlakuan diminta untuk mengisi lembar diari makan yang ada pada buku saku yang berisi sayur dan buah apa saja yang dikonsumsi selama 7 hari ke depan. Setelah 7 hari, dilakukan pertemuan kembali, 
refresh materi, kemudian siswa di kedua kelompok diminta untuk mengisi kuesioner post-test serta mengumpulkan diari makan sayur dan buah yang sudah mereka isi di rumah.

Dalam kuesioner pre-test dan post-test terdapat 10 pertanyaan tentang pengetahuan sayur dan buah seperti manfaat, dampak kekurangan konsumsi, aturan konsumsi sayur dan buah; serta 6 pertanyaan tentang praktik konsumsi sayur dan buah siswa. Tingkat pengetahuan responden kedua kelompok dikategorikan berdasarkan nilai, yaitu berpengetahuan baik apabila nilai pengetahuan $76-100 \%$, kategori cukup apabila nilai $56 \%-75 \%$, dan kategori kurang apabila nilai $<56 \%$ (Nursalam, 2016). Praktik dinilai berdasarkan kuesioner dan dilihat pula pada buku saku untuk kelompok perlakuan. Praktik berdasarkan kuesioner dikategorikan berdasarkan nilai, yaitu nilai 0-2 termasuk kategori kurang, 3-4 kategori cukup, dan 5-6 kategori baik.

Teknik analisis data menggunakan uji independen t-test untuk membandingkan perubahan pengetahuan kelompok kontrol dan perlakuan, paired sample t-test untuk melihat kemaknaan perubahan sebelum dan sesudah perlakuan bila data berdistribusi normal, dan Wilcoxon sign rank test apabila data berdistribusi tidak normal. Dalam penelitian ini, 3 uji statistik tersebut digunakan, karena data kelompok kontrol berdistribusi tidak normal, sedangkan kelompok perlakuan berdistribusi normal. Penelitian ini telah memperoleh persetujuan dari komisi etik FKM Universitas Airlangga dengan nomor 327-KEPK.

\section{HASIL DAN PEMBAHASAN}

\section{Karakteristik Siswa}

Kelompok kontrol memiliki jumlah siswa laki-laki hanya $25 \%$, sedangkan sisanya siswa perempuan. Kelompok perlakuan memiliki jumlah siswa laki-laki yang lebih banyak dari pada siswa perempuan yaitu $62,5 \%$.

\section{Karakteristik Orang Tua Siswa}

Tabel 1. menunjukkan bahwa sebagian besar umur ayah dan ibu siswa baik kelompok kontrol maupun perlakuan termasuk kelompok umur di atas 30 tahun. Pendidikan terakhir orang tua siswa kedua kelompok sebagian besar hanya tamatan sekolah dasar. Pekerjaan dari separuh ayah siswa kelompok kontrol yaitu sebagai wiraswasta, sedangkan ayah siswa kelompok perlakuan sebagian besar bermata pencaharian sebagai petani. Pekerjaan ibu siswa kelompok kontrol mayoritas sebagai petani dan wiraswasta, sementara pekerjaan hampir separuh ibu siswa kelompok perlakuan sebagai petani. Terdapat beberapa ibu siswa dari kedua kelompok yang tidak bekerja.

Berdasarkan hasil tersebut dapat disimpulkan bahwa orang tua siswa memiliki tingkat pendidikan serta pendapatan yang relatif rendah. Rendahnya tingkat pendidikan mempengaruhi pendapatan orang tua sehingga dapat mempengaruhi ketersediaan makanan yang ada di rumah. Hal ini sesuai dengan penelitian yang dilakukan oleh Mohammad dan Madanijah (2015), yang menyatakan bahwa pendapatan keluarga berhubungan dengan konsumsi buah siswa. Semakin rendah pendapatan keluarga, dapat mempengaruhi makanan apa saja yang tersedia di rumah termasuk ketersediaan sayur dan buah di rumah dapat semakin menurun.

Ibu merupakan penyelenggara makanan seharihari dalam rumah tangga. Tingkat pengetahuan ibu sebagai penyelenggara dan pengelola makanan rumah tangga sangat berpengaruh terhadap makanan yang dikonsumsi anggota keluarga sehari-hari. Pendidikan ibu berhubungan dengan konsumsi sayur dan buah anak (Mohammad dan Madanijah, 2015). Ibu yang memiliki tingkat pengetahuan gizi dan kesadaran gizi yang tinggi akan mengenalkan makan sayur dan buah sejak dini, begitu pula sebaliknya.

\section{Pengetahuan dan Praktik Siswa Sebelum diberi Perlakuan}

Hasil penelitian ini menunjukkan bahwa tingkat pengetahuan siswa sebelum diberi perlakuan yaitu sebanyak 65\% siswa kelompok kontrol dan 92,5\% kelompok perlakuan memiliki tingkat pengetahuan yang kurang. Siswa kelompok kontrol memiliki tingkat praktik yang kurang $(30 \%)$, sedangkan tingkat praktik kelompok 
Tabel 1. Karakteristik Orang Tua Siswa

\begin{tabular}{|c|c|c|c|c|}
\hline \multirow[t]{2}{*}{ Karakteristik } & \multicolumn{2}{|c|}{$\begin{array}{c}\text { Kontrol } \\
(\mathbf{n}=\mathbf{2 0})\end{array}$} & \multicolumn{2}{|c|}{$\begin{array}{l}\text { Perlakuan } \\
(n=40)\end{array}$} \\
\hline & $\mathbf{n}$ & $\%$ & n & $\%$ \\
\hline \multicolumn{5}{|l|}{ Umur Ayah (tahun) } \\
\hline $20-30$ & 0 & 0,0 & 2 & 5 , \\
\hline $31-40$ & 7 & 35,0 & 32 & 80,0 \\
\hline $41-50$ & 9 & 45,0 & 6 & 15,0 \\
\hline$>51$ & 3 & 15,0 & 0 & 0,0 \\
\hline \multicolumn{5}{|l|}{ Umur Ibu (tahun) } \\
\hline $20-30$ & 0 & 0,0 & 2 & 5,0 \\
\hline $31-40$ & 17 & 85,0 & 37 & 92,5 , \\
\hline $41-50$ & 3 & 15,0 & 1 & 2,5 \\
\hline \multicolumn{5}{|l|}{ Pendidikan terakhir Ayah } \\
\hline Sekolah Dasar & 13 & 65,0 & 35 & 87,5 \\
\hline Sekolah Menengah Pertama & 1 & 5,0 & 4 & 10,0 \\
\hline Sekolah Menengah Dasar & 4 & 20,0 & 0 & 0,0 \\
\hline Perguruan Tinggi & 1 & 5,0 & 1 & 2,5 \\
\hline \multicolumn{5}{|l|}{ Pendidikan Terakhir Ibu } \\
\hline Sekolah Dasar & 9 & 45,0 & 27 & 67,5 \\
\hline Sekolah Menengah Pertama & 7 & 35,0 & 7 & 17,5 \\
\hline Sekolah Menengah Dasar & 3 & 15,0 & 6 & 15,0 \\
\hline Perguruan Tinggi & 1 & 5,0 & 0 & 0,0 \\
\hline \multicolumn{5}{|l|}{ Pekerjaan Ayah } \\
\hline Petani & 6 & 30,0 & 34 & 85,0 \\
\hline Buruh tani & 3 & 15,0 & 0 & 0,0 \\
\hline Wiraswasta & 10 & 50,0 & 5 & 12,5 \\
\hline Pegawai Negeri Sipil & 1 & 5,0 & 1 & 2,5 \\
\hline \multicolumn{5}{|l|}{ Pekerjaan Ibu } \\
\hline Tidak bekerja & 4 & 20,0 & 14 & 35,0 \\
\hline Petani & 6 & 30,0 & 18 & 45,0 \\
\hline Buruh tani & 3 & 15,0 & 0 & 0,0 \\
\hline Wiraswasta & 6 & 30,0 & 8 & 20,0 \\
\hline Pegawai Negeri Sipil & 1 & 5,0 & 0 & 0,0 \\
\hline
\end{tabular}

perlakuan yang memiliki tingkat praktik kurang adalah 57,5\% (Tabel 2).

Rendahnya tingkat pengetahuan siswa bisa saja terjadi karena kurangnya informasi yang mereka peroleh tentang pentingnya konsumsi sayur dan buah. Menurut hasil wawancara dengan pihak sekolah dan siswa menyatakan bahwa belum pernah ada penyuluhan terkait sayur dan buah sebelumnya. Hal ini sesuai dengan penelitian yang dilakukan Rahayu dan Pribadi (2012) yang menyatakan bahwa paparan informasi dan media merupakan salah satu faktor yang dapat mempengaruhi pengetahuan seseorang. Sehingga perlu adanya penyuluhan atau pendidikan gizi lain yang disampaikan kepada anak usia sekolah dasar untuk meningkatkan pengetahuan mereka tentang gizi.

Tabel 3. menunjukkan bahwa terdapat perbedaan hasil pre-test pengetahuan dan praktik antara kelompok kontrol dan kelompok perlakuan. Berdasarkan hasil uji independent $t$ test pre-test pengetahuan diperoleh nilai signifikansi $\mathrm{p}=0,220(>0,05)$ yang artinya tidak ada perbedaan pengetahuan pada kedua kelompok. Pre-test praktik memiliki nilai signifikansi $\mathrm{p}=0,091(>0,05)$ 
Tabel 2. Tingkat Pengetahuan dan Praktik Pre-test dan Post-test pada Kelompok Kontrol dan Kelompok Perlakuan

\begin{tabular}{|c|c|c|c|c|}
\hline & \multicolumn{2}{|c|}{$\begin{array}{c}\text { Kelompok Kontrol } \\
(\mathbf{n}=\mathbf{2 0})\end{array}$} & \multicolumn{2}{|c|}{$\begin{array}{c}\text { Kelompok Perlakuan } \\
(\mathbf{n}=\mathbf{4 0 )}\end{array}$} \\
\hline & Pre & post & Pre & Post \\
\hline \multicolumn{5}{|c|}{ Pengetahuan } \\
\hline Kurang & $13(65 \%)$ & $12(60 \%)$ & $37(92,5 \%)$ & $4(10 \%)$ \\
\hline Cukup & $7(35 \%)$ & $8(40 \%)$ & $3(7,5 \%)$ & $26(65 \%)$ \\
\hline Baik & $0(0 \%)$ & $0(0 \%)$ & $0(0 \%)$ & $10(25 \%)$ \\
\hline \multicolumn{5}{|l|}{ Praktik } \\
\hline Kurang & $6(30 \%)$ & $14(70 \%)$ & $23(57,5 \%)$ & $12(30 \%)$ \\
\hline Cukup & $6(30 \%)$ & $6(30 \%)$ & $10(25 \%)$ & $21(52,5 \%)$ \\
\hline Baik & $8(40 \%)$ & $0(0 \%)$ & $7(17,5 \%)$ & $7(17,5 \%)$ \\
\hline
\end{tabular}

yang memiliki arti tidak adanya perbedaan praktik pada kelompok kontrol dan perlakuan.

\section{Perbedaan Pengetahuan dan Praktik}

Perbedaan tingkat pengetahuan dan praktik pada kedua kelompok dapat dilihat pada Tabel 2 . Tingkat pengetahuan siswa baik kelompok kontrol maupun perlakuan sebelum diberi perlakuan sebagian besar memiliki tingkat pengetahuan yang kurang (65\%) untuk kelompok kontrol dan kelompok perlakuan $(92,5 \%)$. Setelah diberi perlakuan tingkat pengetahuan kurang semakin menurun, persentase kelompok kontrol yang memiliki tingkat pengetahuan kurang menurun menjadi $60 \%$ dan kelompok perlakuan menjadi $10 \%$.

Tabel 2. menunjukkan tingkat praktik sebelum diberi perlakuan pada kelompok kontrol sebagian besar memiliki tingkat praktik baik (40\%), sedangkan kelompok perlakuan sebagian besar memiliki tingkat praktik kurang (57,5\%). Tingkat praktik kelompok kontrol setelah diberi perlakuan yang memiliki tingkat praktik kurang mengalami peningkatan menjadi 70\%, sedangkan kelompok perlakuan yang memiliki tingkat praktik kurang menurun menjadi 30\% setelah diberi perlakuan

Tabel 3. menunjukkan hasil uji statistik independen $t$ test diperoleh nilai signifikansi pengetahuan $p=0,421$ yang lebih dari 0,05 , yang artinya tidak ada perbedaan pengetahuan kelompok kontrol dan perlakuan. Nilai signifikansi praktik diperoleh hasil 0,810 di mana angka ini melebihi 0,05 , yang memiliki arti tidak adanya perbedaan praktik antara kedua kelompok.
Apabila dilihat dari rata-rata antara kedua kelompok, rata-rata pengetahuan $(66,3 \pm 12,8)$ dan praktik $(3,1 \pm 1,4)$ siswa kelompok perlakuan memiliki rata-rata lebih tinggi dari pada kelompok kontrol dengan rata-rata pengetahuan $(43,5 \pm 15,0)$ dan rata-rata praktik $(1,8 \pm 1,2)$. Hasil penelitian ini membuktikan bahwa pendidikan gizi dengan media buku saku lebih menunjukkan hasil yang lebih baik/efektif dalam meningkatkan pengetahuan dan praktik siswa tentang mengonsumsi sayur dan buah, walaupun belum dapat dibuktikan secara statistik. Hal ini dapat terjadi karena penyuluhan dengan media buku saku dapat memberikan materi yang lebih lengkap dan ukurannya yang kecil sehingga lebih memudahkan siswa untuk membaca buku saku tersebut di mana saja. Ditambah dengan adanya lembar diari makan, yang membuat siswa semakin rajin untuk mengonsumsi dan menuliskan sayur dan buah apa saja yang mereka konsumsi setiap harinya. Penelitian ini sejalan dengan penelitian yang dilakukan oleh Achmadi (2015) yang juga menunjukkan bahwa penggunaan media buku saku dapat meningkatkan pengetahuan anak tentang pemilihan jajanan.

Tabel 3. menunjukkan hasil uji paired sample t-tes pada kelompok perlakuan yang diberi pendidikan gizi dengan media buku saku memiliki nilai signifikansi pengetahuan $p=0,000$ dan praktik $p=0,000(<0,05)$ yang berarti adanya perbedaan yang cukup signifikan antara sebelum dan setelah diberi perlakuan pendidikan gizi dengan media buku saku atau dengan kata lain adanya pengaruh penggunaan media buku saku terhadap peningkatan pengetahuan dan praktik tentang 
Tabel 3. Efektifitas Pendidikan Gizi tentang Pentingnya Konsumsi Sayur dan Buah dengan Media Leaflet dan Buku Saku

\begin{tabular}{|c|c|c|c|}
\hline & $\begin{array}{c}\text { Kelompok Kontrol } \\
(\mathrm{n}=\mathbf{2 0})\end{array}$ & $\begin{array}{c}\text { Kelompok Perlakuan } \\
(\mathrm{n}=\mathbf{4 0})\end{array}$ & Pvalue \\
\hline \multicolumn{4}{|l|}{ Pengetahuan } \\
\hline -Pre-test & $40,5 \pm 12,3$ & $31,5 \pm 10,3$ & $0,220^{1}$ \\
\hline -Post-test & $43,5 \pm 15,0$ & $66,3 \pm 12,8$ & $0,421^{1}$ \\
\hline -p value & & $0,000^{2}$ & \\
\hline \multicolumn{4}{|l|}{ Praktik } \\
\hline -Pre-test & $3,6 \pm 2,3$ & $2,6 \pm 1,8$ & $0,091^{1}$ \\
\hline -Post-test & $1,8 \pm 1,2$ & $3,1 \pm 1,4$ & $0,810^{1}$ \\
\hline -p value & & $0,000^{2}$ & \\
\hline
\end{tabular}

Keterangan: ${ }^{1}=$ independent $t$-test

$2=$ paired $t$-test

pentingnya mengonsumsi sayur dan buah pada kelompok perlakuan. Rata-rata selisih pengetahuan sebelum dan sesudah diberi perlakuan mengalami peningkatan sebesar 34,75 poin, sedangkan peningkatan rata-rata praktik sebesar 0,5 poin.

Media buku saku berpengaruh dalam peningkatan pengetahuan dan praktik siswa, hal ini sejalan dengan penelitian yang dilakukan oleh Achmadi (2015), yang menyatakan bahwa pendidikan gizi tentang makanan jajanan sehat dengan media buku saku mempengaruhi pengetahuan pemilihan jajanan pada anak SD Muhammadiyah 16 Surakarta. Penelitian yang dilakukan Eliana dan Sholikhah (2012), juga menunjukkan bahwa penggunaan media buku saku berpengaruh terhadap pengetahuan siswa. Penelitian ini sesuai pula dengan penelitian Agustin (2014), yang menyatakan bahwa penggunaan booklet sebagai media pendidikan kesehatan dapat mempengaruhi pengetahuan kesehatan siswa. Tabel 4. menunjukkan hasil uji statistik menggunakan Wilcoxon sign rank test. Hasil uji tersebut diperoleh untuk pengetahuan $p=0,052(>0,05)$ dan praktik $p=0,001(<0,05)$. Berdasarkan hasil $p$ value, tidak ada pengaruh penggunaan media leaflet dalam meningkatkan pengetahuan namun berpengaruh pada praktik kelompok kontrol.

Hasil penelitian ini berbeda dengan penelitian yang dilakukan oleh Ambarwati, dkk (2014), yang membuktikan bahwa penggunaan media leaflet berpengaruh signifikan pada pendidikan kesehatan tentang bahaya merokok pada SDN 78 Sabrang Lor Mojosongo Surakarta. Menurut hasil wawancara
Tabel 4. Pengaruh Pendidikan Gizi dengan Media Leaflet pada Kelompok Kontrol

\begin{tabular}{lrlrl}
\hline & \multicolumn{2}{c}{ Pengetahuan } & \multicolumn{2}{c}{ Praktik } \\
\cline { 2 - 5 } & n & p value & n & p value \\
\hline Negative Ranks & 1 & 0,052 & 14 & 0,001 \\
Positive Ranks & 9 & & 0 & \\
Ties & 10 & & 6 & \\
\hline
\end{tabular}

dengan beberapa siswa serta hasil pengamatan peneliti, dapat disimpulkan bahwa siswa merasa sedikit bingung dengan alur membaca leaflet karena sewaktu dibagikan leaflet mereka membaca dari bagian akhir leaflet terlebih dahulu, mereka tidak menyadari yang mana bagian awal leaflet, serta karena leaflet ini hanya berupa satu lembar kertas yang menyebabkan leaflet ini rawan untuk hilang, sehingga siswa tidak bisa membaca lagi materi yang ada dalam leaflet. Leaflet lebih banyak berisi materi dari pada gambar yang menyebabkan siswa menjadi kurang tertarik untuk membaca leaflet (Ambarwati, 2014). Hal ini pula yang menyebabkan siswa menjadi lupa dengan materi yang telah disampaikan menggunakan media leaflet, sehingga nilai pengetahuan mereka tidak meningkat secara signifikan.

Leaflet tidak mempengaruhi peningkatan pengetahuan siswa dapat dikarenakan alasan tersebut di atas, namun bukan berarti hal tersebut menyebabkan siswa tidak bisa mengaplikasikan materi ke dalam kehidupan sehari-hari. Sikap dan praktik yang dilakukan seseorang biasanya dipengaruhi oleh faktor pengalaman sendiri atau 
orang terdekat, walaupun seseorang berpengetahuan tentang sayur dan buah rendah, belum tentu memiliki sikap dan praktik tentang konsumsi sayur dan buah yang rendah pula (Notoadmodjo, 2007). Siswa bisa saja lupa materi yang disampaikan secara detail, namun mereka memahami poin penting materi yang tertera pada leaflet yaitu mengonsumsi sayur dan buah. Hal ini dikarenakan leaflet yang diberikan dapat menyampaikan materi dengan lugas, tersurat dengan jelas dan terdapat beberapa gambar ditambah dengan konsentrasi siswa saat diberikan materi, ditambah pula dengan ketersediaan dan kebiasaan orang tua siswa, sehingga dapat memunculkan niatan siswa untuk mengonsumsi sayur dan buah. Hal ini juga dapat dipengaruhi oleh beberapa faktor lain seperti faktor kebiasaan makan orang tua siswa serta ketersediaan sayur dan buah di rumah siswa, seperti hasil penelitian terdahulu yang dilakukan oleh Dejesetya (2016), yang menyatakan bahwa faktor yang mempengaruhi konsumsi sayur dan buah pada anak yaitu preferensi makan, pengaruh dari orang tua, ketersediaan sayur dan buah dalam keluarga, pengaruh teman sebaya, pengaruh media, pendidikan orang tua, pekerjaan orang tua, pengetahuan gizi, serta lingkungan sosial dan budaya. Apabila di rumah tersedia sayur dan buah yang cukup, didukung dengan kebiasaan orang tua yang selalu makan sayur dan buah dapat menyebabkan anak menjadi suka makan sayur dan buah. Sehingga media informasi bukan satusatunya faktor yang dapat mempengaruhi praktik konsumsi sayur dan buah anak sekolah dasar.

\section{Diari Makan}

Diari makan siswa menunjukkan buah dan sayur apa saja yang paling sering dikonsumsi oleh siswa. Berdasarkan Tabel 5. hasil diari makan siswa kelompok perlakuan menunjukkan bahwa konsumsi sayur dan buah siswa fluktuatif atau tidak stabil, karena adanya naik turunnya konsumsi sayur dan buah. Dari tujuh hari yang diamati, hari ketiga merupakan hari terbanyak makan sayur. Sebanyak 25 siswa makan sayur pada hari tersebut. Sayur yang paling banyak dikonsumsi selama tujuh hari tersebut antara lain sawi, kubis, dan kangkung. Konsumsi buah siswa dari tujuh hari diamati, menunjukkan bahwa yang paling banyak mengonsumsi buah pada hari keempat yaitu sebanyak 25 siswa. Buah yang paling sering dikonsumsi yaitu pisang dan salak. Sayur dan buah yang paling sering dikonsumsi siswa karena sayur dan buah tersebut yang paling sering tersedia di rumah, mudah diperoleh dan harganya murah.

Tabel 5. Diari Makan Sayur dan Buah

\begin{tabular}{|c|c|c|c|c|}
\hline \multirow{2}{*}{$\begin{array}{c}\text { Hari } \\
\text { ke- }\end{array}$} & \multicolumn{2}{|c|}{$\begin{array}{l}\text { Jumlah siswa yang } \\
\text { konsumsi }\end{array}$} & \multicolumn{2}{|c|}{ Variasi } \\
\hline & Sayur & Buah & Sayur & Buah \\
\hline 1 & 19 & 15 & $\begin{array}{l}\text { Sawi, kangkung, brokoli, wortel, tauge, } \\
\text { kentang, kuningan, kecambah, bunga kol }\end{array}$ & $\begin{array}{l}\text { Jeruk, belimbing, semangka, apel, } \\
\text { pisang, anggur, }\end{array}$ \\
\hline 2 & 20 & 18 & $\begin{array}{l}\text { Kubis, kangkung, sawi, bayam, kuningan, } \\
\text { terong, labu siam }\end{array}$ & $\begin{array}{l}\text { Semangka, nanas, pisang, jeruk, salak, } \\
\text { apel, jambu, nangka, mangga }\end{array}$ \\
\hline 3 & 25 & 21 & $\begin{array}{l}\text { Bayam, kangkung, labu siam, sawi, wortel, } \\
\text { terong, kacang panjang, brokoli, bunga kol, } \\
\text { pare, kubis, }\end{array}$ & $\begin{array}{l}\text { Semangka, salak, jeruk, nanas, pepaya, } \\
\text { pisang, alpukat }\end{array}$ \\
\hline 4 & 17 & 25 & $\begin{array}{l}\text { Bayam, rabusa, sawi, kubis, kentang, } \\
\text { kangkung, kuningan, }\end{array}$ & $\begin{array}{l}\text { Pepaya, anggur, jeruk, pisang, } \\
\text { semangka, sawo, salak, anggur, apel, } \\
\text { mangga, }\end{array}$ \\
\hline 5 & 16 & 18 & $\begin{array}{l}\text { Wortel, kacang panjang, daun singkong, } \\
\text { kuningan, bunga kol, kubis, sawi, kentang, }\end{array}$ & $\begin{array}{l}\text { Pisang, salak, jambu, nangka, } \\
\text { semangka, }\end{array}$ \\
\hline 6 & 10 & 13 & $\begin{array}{l}\text { Sawi, kubis, jagung, bunga kol, tauge, } \\
\text { kacang panjang, kuningan, rabusa, }\end{array}$ & $\begin{array}{l}\text { Apel, salak, semangka, anggur, } \\
\text { nangka, alpukat, pepaya }\end{array}$ \\
\hline 7 & 5 & & Sawi, rabusa, kubis & \\
\hline
\end{tabular}


Kondisi ini sesuai dengan data BPS Kabupaten Lumajang tahun 2016 yang menyatakan bahwa jenis sayur dan buah yang sering dikonsumsi oleh siswa tersebut merupakan hasil pertanian lokal wilayah Lumajang, serta daerah Kandang Tepus merupakan bagian dari Kecamatan Senduro yang merupakan daerah penghasil sayur dan buah untuk wilayah Lumajang. Ketersediaan sayur dan buah di rumah merupakan salah satu faktor yang mempengaruhi pola konsumsi sayur dan buah anak sekolah (Dewantari dan Widianto, 2011). Hal ini didukung dengan penelitian yang dilakukan oleh Afif (2017) yang menyatakan bahwa sebagian besar rumah tangga yang memiliki tingkat ketersediaan sayur dan buah kurang. Penelitian ini masih memiliki berbagai macam keterbatasan yaitu seperti jumlah siswa kelompok kontrol yang kurang dari 30 siswa.

\section{KESIMPULAN DAN SARAN}

Adanya penggunaan media buku saku sebagai salah satu media pendidikan gizi mengenai pentingnya mengonsumsi sayur dan buah dapat meningkatkan pengetahuan dan praktik siswa sekolah dasar. Media buku saku lebih efektif dalam meningkatkan pengetahuan dan praktik siswa pada kelompok perlakuan dari pada kelompok kontrol yang diberikan media leaflet.

Perlu adanya program atau pendidikan gizi seperti tentang pentingnya mengonsumsi sayur dan buah yang dilakukan secara berkelanjutan pada siswa sekolah dasar untuk meningkatkan konsumsi sayur dan buah pada siswa; serta perlu adanya penelitian lebih lanjut dan menambahkan kolom frekuensi dan jumlah sayur dan buah yang dikonsumsi pada diari makan.

\section{DAFTAR PUSTAKA}

Achmadi, A.D. (2015). Pengaruh pendidikan gizi dengan media buku saku terhadap peningkatan pengetahuan dalam pemilihan jajanan anak SD Muhammadiyah 16 Surakarta. Diakses dari http://eprints.ums.ac.id/38164/3/02.\%20 Naskah\%20Publikasi.pdf.

Afif, P.A. (2017). Pengaruh peran ibu dalam menentukan pola konsumsi keluarga terhadap tingkat konsumsi sayur dan buah pada anak usia sekolah dasar di Desa Senduro Kabupaten Lumajang. (Skripsi tidak dipublikasikan). Universitas Airlangga, Surabaya.

Agustin, M. (2014). Efektifitas pendidikan kesehatan media booklet dibandingkan audio visual terhadap pengetahuan orang tua tentang karies gigi pada anak usia 5-9 tahun di Desa Makamhaji (Skripsi, Universitas Muhammadiyah Surakarta, Surakarta). Diakses dari http://eprints.ums.ac.id/32230/26/02.\%20 NASKAH\%20PUBLIKASI.pdf.

Amalia, L, Endro, O.P, \& Damanik, M.R.M. (2012). Preferensi dan frekuensi makanan jajanan pada anak sekolah dasar di Kecamatan Cijeruk, Kabupaten Bogor. Jurnal Gizi dan Pangan, 7(2), 119-126. Diakses dari http:// journal.ipb.ac.id/index.php/jgizipangan/article/ view/12374/9459.

Ambarwati, Khoirotul U., A., Kurniawati, F., Diah K, T., \& Darojah, S. (2014). Media leaflet, video, dan pengetahuan siswa SD tentang bahaya merokok (studi pada siswa SDN 78 Sabrang Lor Mojosongo Surakarta). KEMAS, 10(1), 7-13. Diakses dari https://journal.unnes.ac.id/nju/ index.php/kemas/article/download/3064/3081

Anggraeni, A.S. (2016). Correlation between consumption pattern of fruit and vegetables with risk of obesity in school-age children. (Skripsi tidak dipublikasikan). Universitas Airlangga, Surabaya.

Badan Penelitian dan Pengembangan Kesehatan RI. (2013). Riset kesehatan dasar (RISKESDAS 2013). Jakarta: Kementrian Kesehatan RI.

Badan Pusat Statistik Kabupaten Lumajang. (2016). Kabupaten Lumajang dalam angka 2016. Lumajang: BPS Kabupaten Lumajang.

Dhaneswara, D.P. (2016). Perilaku makan sayur dan buah pada mahasiswa asrama universitas airlangga berdasarkan theory of planned behavior (Skripsi tidak dipublikasikan). Universitas Airlangga, Surabaya.

Dewantari, N.M. dan Widiani, A. (2011). Fruits and vegetables consumption pattern in school children. Jurnal Skala Husada, 8(2), 119125. Diakses dari http://perpustakaan.litbang. depkes.go.id/otomasi/index.php? $\mathrm{p}=$ show_ detail\&id=33799.

Dejesetya, P.M. (2016). Pola konsumsi sayur dan buah anak usia 4-6 tahun pada masyarakat pesisir Desa Randusanga Kulon Brebes (Skripsi tidak dipublikasikan). Semarang: Universitas Negeri Semarang. 
Dhian, Y.F. (2009). Faktor yang berhubungan dengan tingkat konsumsi sayur pada anak sekolah dasar (SD) Kembangarum 01/02 Kecamatan Semarang Barat Kota Semarang (Skripsi tidak dipublikasikan). Universitas Negeri Semarang, Semarang.

Eliana, D. \& Solikhah. (2012). Pengaruh buku saku gizi terhadap tingkat pengetahuan gizi pada anak kelas 5 Muhammadiyah Dadapan Desa Wonokerto Kecamatan Turi Kabupaten Sleman Yogyakarta. Jurnal Kesmas, 6(2), 162-232. Diakses dari http://journal.uad.ac.id/index.php/ KesMas/article/view/1021/757.

Kemenkes RI. (2014). Pedoman gizi seimbang. Jakarta: Kementerian Kesehatan RI.

Lestari, A.D. (2013). Faktor-faktor yang berhubungan dengan perilaku konsumsi buah dan sayur pada siswa SMP Negeri 226 Jakarta Selatan Tahun 2012 (Skripsi tidak dipublikasikan). Universitas Islam Negeri (UIN) Syarif Hidayatullah Jakarta, Tangerang.

Manore, M.M., Meyer, N.L., \& Thompson, J. (2009). Sport nutrition for health and performance. Champaign IL: Human Kinetics.

Mohammad, A. \& Madanijah, S. (2015). Konsumsi buah dan sayur anak usia sekolah dasar di Bogor. Jurnal Gizi Pangan, 10(1), 71-76. Diakses dari http://journal.ipb.ac.id/index.php/ jgizipangan/article/view/9315.
Mulyani, E.Y., Mustikawati, I.S., Handayani, P., Rumana, N.A. (2014). Pengetahuan, sikap, dan perilaku gizi seimbang anak sekolah dasar di SDN GU 12 Pagi. Jurnal Abdimas, 1(1), 98-104. Diakses dari ejurnal.esaunggul.ac.id/ index.php/ABD/article/download/1196/1091.

Notoatmodjo, S. (2007). Kesehatan masyarakat. ilmu dan seni. Jakarta: Rineka Cipta.

Nursalam. (2016). Metodologi penelitian ilmu keperawatan: pendekatan praktis. (Edisi 4). Jakarta: Salemba Medika.

Rahayu, E.S. \& Pribadi, P. (2012). Kadar vitamin dan mineral dalam buah segar dan manisan basah carica dieng (Carica pubescens Lenne \& K. Koch). Biosantifika, 4(2), 89-97. Diakses dari https://journal.unnes.ac.id/nju/index.php/ biosaintifika/article/view/2273/2326.

Siagian, D.M., Mursyid, A., \& Hartini, T.N.S. (2017). Hubungan konsumsi sayur dan buah dengan obesitas pada anak SD Kelas IV-VI di SD Pantekosta Magelang Tahun 2017 (Skripsi tidak dipublikasikan). Poltekkes Kemenkes Yogyakarta, Yogyakarta. 